Itot Bian Raharjo, Warih Handayaningrum, Autar Abdillah

EFEKTIVITAS PENGGUNAAN CHORD DALAM MENINGKATKAN

KEMAMPUAN BELAJAR MENCIPTA LAGU ANAK USIA DINI

\title{
EFEKTIVITAS PENGGUNAAN CHORD DALAM MENINGKATKAN \\ KEMAMPUAN BELAJAR MENCIPTA LAGU ANAK USIA DINI \\ (Class Action Research pada Guru PAUD di Kabupaten Kediri)
}

\author{
Itot Bian Raharjo ${ }^{1}$, Warih Handayaningrum², Autar Abdillah ${ }^{3}$ \\ Pascasarjana Pendidikan Seni Budaya Universitas Negeri Surabaya ${ }^{1,2,3}$ \\ Email: itotbian@unpkediri.ac.id,warihhandayaningrum@unesa.ac.id, autar.unesa@gmail.com,
}

\begin{abstract}
Abstact: This research is motivated by the need for songs as PAUD learning media in Kediri Regency. In general, teachers only use old songs, composing song lyrics. This study uses the Class Action Research approach which was conducted from March to October 2019. The results of the data analysis included 12 respondents $(80 \%)$ in the first cycle, 5 respondents $(33.3 \%)$ in the second cycle, and 2 respondents (13.3\%) in cycle III that has not yet reached. It can also be seen that in the third cycle, the number of respondents reached 13 people with a percentage of $86.6 \%$. It can be concluded that the use of chords in learning to create early childhood songs was successful, the action hypothesis in this study was declared acceptable.
\end{abstract}

Key Words : Chord, compose a song, Childhood

\begin{abstract}
Abstrak: Penelitian ini dilatarbelakangi kebutuhan lagu sebagai media pembelajaran PAUD di Kabupaten Kediri. Pada umumnya guru hanya menggunakan lagu lama, penggubahan lirik lagu. Penelitian ini menggunakan pendekatan Class Action Research yang dilaksanakan mulai Maret Oktober 2019. Hasil analisis data terdapat 12 responden (80\%) di siklus I, 5 responden $(33,3 \%)$ di siklus II, dan 2 responden $(13,3 \%)$ di siklus III yang belum mencapai. Dapat diketahui pula pada siklus ke III, responden yang sudah tercapai berjumlah 13 orang dengan prosentase 86,6\%. Dapat disimpulkan bahwa penggunaan chord dalam belajar mencipta lagu anak usia dini berhasil, hipotesis tindakan dalam penelitian ini dinyatakan diterima.
\end{abstract}

Kata Kunci: Chord, Mencipta Lagu, Anak

\section{LATAR BELAKANG}

Pendidikan karakter melalui kegiatan seni di proses pembelajaran di Pendidikan Anak Usia Dini sangatlah berpengaruh secara signifikan, yang mana melalui kegiatan ini anak akan merasakan kebermaknaan dalam memperoleh pengetahuan. Dalam melakukan aktivitas seni, anak dapat memahami segala sesuatu disekitarnya, dari tidak tahu - tahu, abstrak konkrit.

Pembelajaran terpadu sangat cocok untuk diterapkan pada pelaksanaan aktivitas belajar di Pendidikan Anak Usia Dini, Dalam pembelajaran ini, anak akan mendapat pengetahuan dan keterampilan secara menyeluruh sehingga pembelajaran akan lebih bermakna.

Lagu anak harus diciptakan sesuai dengan pengalaman dunia anak. Lirik dengan bahasa realistis anak, sesuai ambitus anak, tangga nada sederhana dan mudah dilagukan yang tidak membuat anak menjadi sulit jika dinyanyikan.

Dalam kegiatan pembelajaran harian, guru menyiapkan perangkat pembelajaran dalam bentuk RPPH. Supaya kegiatan pembelajaran itu membawa dampak kebermaknaan (PAIKEM), maka dimasukkanlah aktivitas bernyanyi di rencana pelaksanaan pembelajaran tersebut. Tentunya guru harus menyiapkan materi lagu yang disesuaikan dengan tema 
pembelajaran. Lagu yang dibawakan bisa dari lagu yang telah ada, menggubah lirik dari lagu yang telah ada, maupun guru menciptakan lagu sendiri.

Kegiatan yang memiliki dampak positif pada perkembangan anak adalah bernyanyi, apalagi jika lagu tersebut sangat disukai olah anak. Metode bernyanyi berperan penting dalam perbendaharaan kata-kata anak. Tahap awal adalah menirukan kata-kata dan menjelaskan makna dari kata yang diucapkan oleh guru, maka anak akan mengenal kata tersebut. Pada tahap awal ini, anak dapat mengembangkan intelegensi melalui daya imajinasi anak yang terealisasi secara langsung dengan baik.

Kita dapat mengetahui kondisi di lapangan bahwa banyak sekali lagu yang diciptakan dengan tujuan komersial. Biasanya lagu yang diciptakan adalah lagulagu bertemakan kehidupan saat ini, baik kalangan remaja-pemuda, maupun dewasa. Lagu tersebut menjadi tidak tepat ketika dibawakan oleh anak pada anak usia dini.

Berdasarkan hasil validasi cipta lagu yang telah peneliti lakukan pada saat "Pelatihan Penciptaan Lagu Anak Usia Dini bagi Guru PAUD di Kabupaten Kediri" yang dilaksanakan pada tanggal 19, 26 Pebruari, dan 05, 12 Maret 2017 dengan peserta berjumlah 28 orang dari 28 kecamatan di Kabupaten Kediri, dapat diidentifikasi bahwa kemampuan guru dalam menciptakan lagu sangat lemah, penggunaan bahasa yang terlalu tinggi bagi anak, penggunaan range melodi yang terlalu luas, harga notasi yang tidak sama ketika dinyanyikan dengan partitur yang dibuat, hal terebut ditunjukkan dari, pembuatan lirik yang tidak runtut.

Dari hasil survey dan observasi yang telah peneliti lakukan secara random, yaitu sebanyak 15 lembaga PAUD yang tersebar di masing-masing wilayah di Kabupaten Kediri (Pare, Kandangan, Kepung, Pagu,
Wates, Papar, Badas, Gurah, Plosoklaten, Plemahan, Semen, Grogol, Tarokan, Kras, dan Mojo) selama 1 bulan pada bulan Nopember 2018 fenomena yang terjadi di lapangan terlihat aktivitas bernyanyi dari kegiatan pembelajaran ini lebih kepada pembawaan lagu yang telah ada dan menggubah lirik dari lagu yang telah ada. Hal tersebut dibenarkan oleh guru serta dinilai memudahkan dalam mempersiapkan kegiatan pembelajaran pada setiap harinya.

Kendala ini dibenarkan juga melalui artikel yang terpublikasi di Pedagogi: Jurnal Anak Usia Dini dan Pendidikan Anak Usia Dini Volume 3 Nomor 3b Desember 2017 Universitas Negeri Padang, seperti yang dipaparkan oleh Indra Yeni dan Irdhan Epria Dharma Putra (2017). Ditunjukkan bahwa penguasaan musikalitas guru di PAUD kurang, sepertinya kekampuan bernyanyi yang lemah dan kurang terampil dalam memainkan alat musik sehingga terkesan hanya memerintah tanpa memberikan contoh terlebih dahulu, dapat ditemukan juga memberikan contoh namun suara yang ditimbulkan tidak enak didengar sehingga anak menjadi tidak tertarik untuk mendengarkan. Apalagi untuk menciptakan lagu karena untuk menciptakan lagu, guruguru harus mempunyai kemampuan musikalitas.

Dari penelitian Refi Yunanda Wicaksono dan Udi Utomo (2017) yang dipublikasikan di Jurnal Seni Musik Universitas Negeri Semarang. Dapat disimpulkan bahwa proses mengenal lagu dikalangan siswa TK Pertiwi I Singodutan adalah melalui orang tua siswa dan guru. Proses awal pengenalan lagu kepada anak melalui orang tua dilakukan dengan cara mengajarkan langsung melalui media elektronik (televisi, handphone, komputer dan internet). Oleh guru dilakukan melalui proses pembelajaran di sekolah. TK Pertiwi menggunakan kurikulum tematik yang menggunakan lagu dalam 
pembelajarannya. Kelebihan dari penulisan penelitian ini lebih kepada peningkatan kompetensi guru dalam menciptakan lagu berbasis tema melalui chord, yang tidak lagi menggunakan lagu lama yang kadang tidak sesuai dengan tema ataupun penggubahan lirik lagu yang telah ada.

Hasil penelitian yang relevan berikutnya adalah penelitian dari Devi Arostiyani (2013) yang dipublikasikan di Jurnal Seni Musik Universitas Negeri Semarang. Pendidikan karakter untuk anak usia dini dapat disampaikan melalui lagu. saat mengajarkan lagu, guru kemudian menjelaskan makna dari lirik/ kalimat yang ada pada lagu maka secara tidak langsung proses pembelajaran karakter ini bisa terintegrasi. Pengamatan terhadap perubahan sikap anak dan tingkah laku anak di sekolah adalah cara untuk mengukur keberhasilan pendidikan karakter di TK Aisyiyah Linggapura tersebut. Kesulitan yang dihadapi guru jika memanfaatkan lagu yang telah ada adalah kesesuaian tema dan nilai/ pesan yang dikehendaki oleh guru tersebut.

Hasil penelitian yang relevan berikutnya adalah penelitian dari Asri Kusumaning Ratri (2016), ditinjau berdasarkan ketercapaian guru dalam menciptakan lagu anak sesuai metode menunjukkan nilai efektif, dari 13 guru sebagai subyek ujicoba pemakaian menghasilkan 13 lagu anak (100\%). Bentuk lagu yang berhasil diciptakan oleh guru menunjukkan nilai baik (73\%). Kelebihan dari penulisan penelitian ini adalah pemberian alternatif atau pilihan tentang langkah-langkah dalam menciptakan lagu melalui chord, identifikasinya adalah tidak semua guru memiliki musikalitas dalam menciptakan lagu.

Dalam belajar mencipta lagu melalui chord, penelitian ini melakukan pemilihan 15 responden dari 26 kecamatan se Kabupaten Kediri yang menguasai/dapat memainkan alat musik seperti gitar dan keyboard. Penentuan 2 alat musik ini menjadi pertimbangan efektivitas dalam mencipta, karena pada umumnya yang dimiliki atau yang familiar dengan masyarakat adalah gitar dan keyboard. Untuk pemraktikannya, 2 alat musik tersebut memiliki trinada yang sama. Contoh: nada dasar $\mathrm{c}=$ do, maka susunan atau skala penjariannya sama yaitu do-mi-sol (1-3-5).

Sebelum menciptakan lagu melalui chord terlebih dahulu kita fahami tentang karakteristik lagu anak usia dini, salah satunya adalah menggunakan ambitus/ jangkauan nada sesuai kemampuan anak, hindari lompatan-lompatan nada yang menyulitkan untuk ditiru, dan gunakan chord dasar yang memudahkan anak membidik nada dengan tepat dari trinada yang ditekan/dimainkan.

Langkah-langkah dalam belajar mencipta lagu anak melalui chord adalah :

1. Menentukan birama lagu (4/4, 3/4, atau 2/4).

2. Menentukan alur chord dengan jumlah birama kelipatan 4 . Biasa 8 bar yang terdiri dari bait lagu (1 kalimat) dan refrain lagu (1 kalimat), kemudian pengulangan (dengan lirik yang sama maupun lirik yang berbeda)

Simulasi pada Bait Lagu (4/4)

|C . . . | F . . . G . . . C . . . |

Simulasi pada Reff

|F .. . C . . G . . C . . |

3. Dari alur chord yang telah ditentukan, langkah selanjutnya adalah memetakan chord dalam bentuk notasi huruf ataupun notasi angka. Alternatif lain adalah melalui penyebutan notasi tersebut (dore-mi-fa-sol-la-si-do')

\section{Bait Lagu}

a. Birama 1, chord $\mathrm{C}=\mathrm{C}-\mathrm{E}-\mathrm{G}(1-3-5)$

b. Birama 2, chord $\mathrm{F}=\mathrm{F}-\mathrm{A}-\mathrm{C}$ (4-6-1)

c. Birama 3, chord $\mathrm{G}=\mathrm{G}-\mathrm{B}-\mathrm{D}$ (5-7-2) 


\section{d. Birama 4, chord $\mathrm{C}=\mathrm{C}-\mathrm{E}-\mathrm{G}(1-3-5)$ Reff}
a. Birama 5, chord $\mathrm{F}=\mathrm{F}-\mathrm{A}-\mathrm{C}(4-6-1)$
b. Birama 6, chord $\mathrm{C}=\mathrm{C}-\mathrm{E}-\mathrm{G}(1-3-5)$
c. Birama 7, chord $\mathrm{G}=\mathrm{G}-\mathrm{B}-\mathrm{D}(5-7-2)$
d. Birama 8, chord $\mathrm{C}=\mathrm{C}-\mathrm{E}-\mathrm{G}(1-3-5)$

4. Dari notasi yang sudah dipetakan, kemudian susun pilihan trinada dari alur chord. Untuk pemilihan notasi, bisa gunakan oktaf dibawahnya (misal dari chord $\mathrm{C}$ berpindah ke $\mathrm{F}$, maka bisa juga gunakan chord $\mathrm{F}$ rendah sehingga notasinya juga terangkai rendah)

a. Birama $1=$ chord $\mathrm{C}$, dipilih notasi $\mathrm{C}$ (1)

b. Birama $2=$ chord $\mathrm{F}$, dipilih notasi $\mathrm{A}$ (6, rendah)

c. Birama $3=$ chord $\mathrm{G}$, dipilih notasi $\mathrm{B}$ (7, rendah)

d. Birama $4=$ chord $\mathrm{C}$, dipilih notasi $\mathrm{C}$ (1)

e. Birama $5=\operatorname{chord} \mathrm{F}$, dipilih notasi $\mathrm{F}$ (4)

f. Birama $6=\operatorname{chord} \mathrm{C}$, dipilih notasi $\mathrm{E}$ (3)

g. Birama $7=$ chord $\mathrm{G}$, dipilih notasi $\mathrm{D}$ (2)

h. Birama $8=$ chord $\mathrm{C}$, dipilih notasi $\mathrm{C}$ (1)

5. Menyusun pilihan notasi ke dalam sukat birama sesuai dengan urutan pilihan notasi.

Simulasi pada Bait Lagu

|1 . . |6 . . |7 . . 1 . . |

Simulasi pada Reff

$|4 \ldots| 3 \ldots|2 \ldots| 1 \ldots \mid$

6. Memberikan jembatan notasi (bridge) antar birama dengan pilihan harga notasi yang terdekat dengan birama berikutnya ( 2 ketuk, 1 ketuk, dan bisa $1 / 2$ ketuk) Simulasi pada Bait Lagu

|1 .5 5 |6.56 6 7..2 | 1 ... |

Simulasi pada Reff |4..4 |3... $2 . .2 \mid 1 \ldots$...

7. Pilih tema lagu
8. Pilih sub tema lagu

9. Membuat deskripsi minimal 2 paragraf dengan kalimat yang runtut

10. Memberi underline pada kalimat yang sesuai dengan pilihan lirik. Ingat: dalam memilih kalimat, sesuaikanlah dengan notasi yang sudah tersusun.

11. Lagu siap untuk digunakan.

\section{METODE}

Responden penelitian ini adalah 15 guru PAUD di Kabupaten Kediri yang dipilih dengan kriteria memiliki kemampuan bermain alat musik gitar atau keyboard. Penelitian ini menggunakan pendekatan Class Action Research dengan pelaksanaannya yang dilakukan selama 7 bulan, terhitung mulai Maret sampai dengan Oktober 2019, mulai dari identifikasi masalah hingga pelaporan hasil penelitian. Penentuan pelaksanaan pembelajaran cipta lagu anak dilakukan setiap pulang sekolah di hari sabtu pukul 11.00 sampai selesai selama analisis data dilakukan, kemudian tempat pelaksanaan penelitian adalah di Aula Dinas Pendidikan Kabupaten Kediri dan gedung pertemuan IGTKI-PGRI Kabupaten Kediri. Pada pelaksanaannya setiap guru diwajibkan membawa alat musik sesuai dengan kompetensinya agar langkah-langkah dalam belajar mencipta lagu anak ini dapat dilaksanakan sesuai tahapan.

Model penelitian Class Action Research Kemmis dan Mc. Taggart dengan 4 komponen yaitu perencanaan, tindakan, observasi dan refleksi dalam suatu spiral yang terkait. Instrumen yang digunakan dalam pengumpulan data adalah observasi, angket, dan dokumentasi.

Alat ukur yang digunakan berupa lembar obsevasi, antara lain: pemilihan notasi pada susunan notasi chord (Trinada) dan pemilihan bridge/penghubung antar notasi pada birama selanjutnya. Dengan format 
Itot Bian Raharjo, Warih Handayaningrum, Autar Abdillah

EFEKTIVITAS PENGGUNAAN CHORD DALAM MENINGKATKAN

KEMAMPUAN BELAJAR MENCIPTA LAGU ANAK USIA DINI

lembar penilaian sebagai berikut:

Tabel 1. Instrumen Lembar Penilaian Unjuk Kerja Penggunaan Chord dalam Meningkatkan Kemampuan Belajar Mencipta Lagu Anak Usia Dini pada Siklus ...

\begin{tabular}{|c|c|c|c|c|c|c|c|}
\hline \multirow{3}{*}{ No. } & \multirow{3}{*}{ Nama Resp. } & \multicolumn{6}{|c|}{ Aspek yang Dinilai } \\
\hline & & \multicolumn{4}{|c|}{$\begin{array}{c}\text { Pemilihan Notasi Trinada } \\
\& \\
\text { Pemilihan Bridge } \text { antar } \\
\text { Notasi }\end{array}$} & \multicolumn{2}{|c|}{$\begin{array}{c}\text { Kriteria Ketuntasan } \\
\text { Minimal } \\
\mathbf{7 5 \%} \\
\end{array}$} \\
\hline & & 1 & 2 & 3 & 4 & $\begin{array}{l}\text { Belum } \\
\text { Tuntas }\end{array}$ & Tuntas \\
\hline 1. & $\ldots \ldots \ldots$ & & & & & & \\
\hline 2. & $\ldots \ldots \ldots$ & & & & & & \\
\hline \multicolumn{2}{|c|}{ Jumlah } & & & & & & \\
\hline Pros & & & & & & & \\
\hline
\end{tabular}

Tabel 2. Kriteria Penilaian

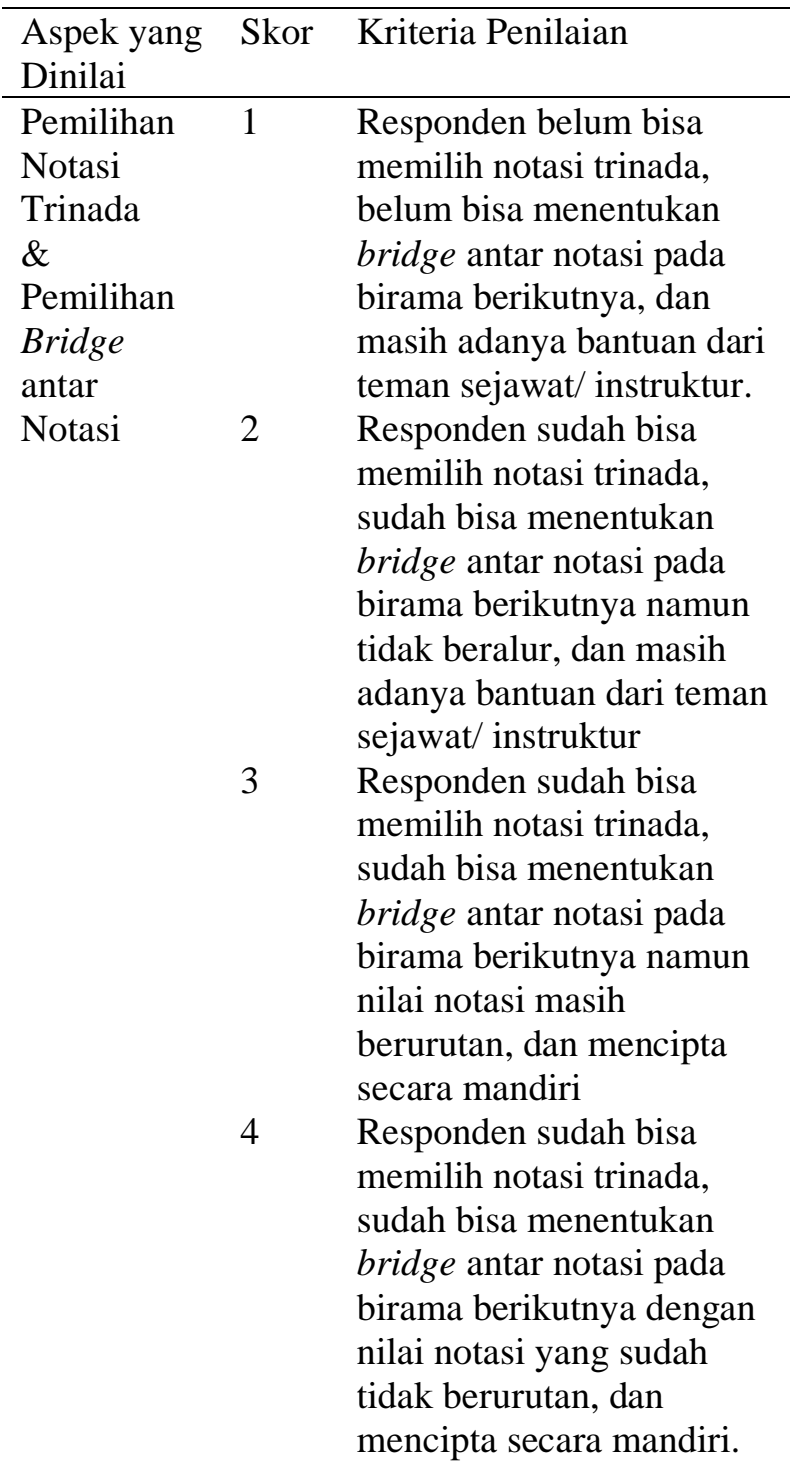

Berdasarkan tabel di atas, hasil analisis pada siklus...pada pemilihan notasi trinada dan pemilihan bridge antar notasi, maka :

1. Terdapat ......responden $(\ldots . . \%)$ yang mendapatkan skor 4,

2. Terdapat ......responden $(\ldots . . \%)$ yang mendapatkan skor 3,

3. Terdapat ......responden $(\ldots . . \%)$ yang mendapatkan skor 2, dan

4. Terdapat, ......responden $(\ldots \ldots \%)$ yang mendapatkan skor 1 .

Tinggi rendahnya kompetensi yang diharapkan dalam proses belajar mencipta lagu anak usia dini diketahui dari tabulasi hasil observasi yang dilakukan. Diharapkan melalui penggunaan chord dapat mengefektifkan kemampuan belajar mencipta lagu anak usia dini. Analisis data untuk keberhasilan penggunaan chord, adalah sebagai berikut:

$$
P=\frac{f}{N} \times 100 \%
$$

Keterangan:

$\mathrm{P} \quad=$ Prosentase yang mendapatkan skor

$f \quad=$ Nilai yang diperoleh responden

$\mathrm{N} \quad=$ Jumlah keseluruhan responden

Penelitian ini sudah mencapai ketuntasan apabila kriterianya di atas $75 \%$, Responden sudah bisa memilih notasi trinada, sudah bisa menentukan bridge antar notasi pada birama berikutnya dengan nilai notasi yang sudah tidak berurutan, dan mencipta secara mandiri.

\section{HASIL}

Pra Siklus

Pelaksanaannya dilakukan 1 kali pertemuan yang dilaksanakan tanggal 6 Juli 2019 dengan agenda pembelajaran teori 
dasar musik. Peserta yang menghadiri pada pertemuan pertama adalah 26 responden yang tersebar dari 26 Kecamatan se Kabupaten Kediri. Berdasarkan hasil dari tanya jawab dan angket yang dikumpulkan, peneliti mendapatkan hasil yaitu dari 26 responden yang menghadiri, sebanyak 15 responden yang memiliki kemampuan memainkan alat musik (2 orang bisa memainkan keyboard dan 13 orang bisa memainkan gitar). Dari hasil observasi dan angket yang disebar pada tahapan awal ini dipilihlah 15 responden yang pada tahap selanjutnya dijadikan subjek penelitian.

\section{Class Action Research - Siklus I}

Pelaksanaan class action research pada siklus I dilakukan 1 kali pertemuan. Siklus ini dilaksanakan tanggal 20 Juli 2019 dengan dengan jumlah responden adalah 15 orang guru PAUD. Pada siklus I, pembelajaran dilaksanakan sesuai perencanaan yang telah ditetapkan dengan mempraktikan belajar mencipta lagu anak usia dini melalui penggunaan chord sesuai dengan tahapan-tahapan. Hasil pengamatan sampai dengan hasil belajar mencipta dapat diketahui pada siklus, dengan hasil yaitu:

Tabel 3. Hasil Analisis Data

Penggunaan Chord dalam Meningkatkan Kemampuan Belajar Mencipta Lagu Anak Usia Dini pada Siklus I

\begin{tabular}{lllll}
\hline No & $\begin{array}{l}\text { Aspek yang } \\
\text { dinilai }\end{array}$ & Kriteria & $\begin{array}{l}\text { Jumlah/ } \\
\text { Anak }\end{array}$ & \% \\
\hline 1 & Pemilihan Notasi & 4 & - & $0 \%$ \\
& Trinada dan & 3 & 3 & $20 \%$ \\
& Pemilihan Bridge & 2 & 10 & $66,7 \%$ \\
& antar Notasi & 1 & 2 & $13,3 \%$ \\
\hline Jumlah & & 15 & $100 \%$ \\
\hline
\end{tabular}

Berdasarkan tabel di atas, hasil analisis pada siklus I pada pemilihan notasi trinada dan pemilihan bridge antar notasi adalah :

1. Terdapat 0 responden $(0 \%)$ yang mendapatkan skor 4,
2. Terdapat 3 responden $(20 \%)$ yang mendapatkan skor 3,

3. Terdapat 10 responden $(66,7 \%)$ yang mendapatkan skor 2, dan

4. Terdapat, 2 responden $(13,3 \%)$ yang mendapatkan skor 1 .

\section{Tahap Refleksi}

Dari hasil observasi pada pelaksanaan siklus I dapat diketahui bahwa responden masih banyak yang mengalami kesulitan dan kebingungan. Terdapat 12 responden yang belum mengalami ketuntasan pada Pemilihan Notasi Trinada dan Pemilihan Bridge antar Notasi dan masih dibantu oleh teman sejawat/instruktur, responden tersebut adalah tersebut adalah Yessy, Amy, Hany, Nurul, Miftahul, Elis, Irna, Orbiyati, Ena, Kunariyati, Ida, dan Weni.

\section{Class Action Research - Siklus II}

Siklus II dilaksanakan selama satu pertemuan yaitu pada tanggal 03 Agustus 2019 sebanyak 15 responden. Pada siklus II, proses belajar mencipta lagu anak usia dini melalui chord berlangsung sesuai rencana pembelajaran yang telah ditetapkan. Data hasil pengamatan terhadap proses pembelajaran pada siklus ini adalah sebagai berikut:

Tabel 4. Hasil Analisis Data

Penggunaan Chord dalam Meningkatkan Kemampuan Belajar Mencipta Lagu Anak Usia Dini pada Siklus II

\begin{tabular}{lllll}
\hline No & $\begin{array}{l}\text { Aspek yang } \\
\text { dinilai }\end{array}$ & Kriteria & $\begin{array}{l}\text { Jumlah/ } \\
\text { Anak }\end{array}$ & \% \\
\hline 1 & Pemilihan Notasi & 4 & 4 & $26,7 \%$ \\
& Trinada dan & 3 & 6 & $40 \%$ \\
& Pemilihan Bridge & 2 & 5 & $33,3 \%$ \\
& antar Notasi & 1 & - & $0 \%$ \\
\hline Jumlah & & 15 & $100 \%$ \\
\hline
\end{tabular}

Berdasarkan tabel di atas, hasil analisis pada siklus II pada pemilihan notasi trinada dan pemilihan bridge antar notasi adalah : 
Itot Bian Raharjo, Warih Handayaningrum, Autar Abdillah

EFEKTIVITAS PENGGUNAAN CHORD DALAM MENINGKATKAN

KEMAMPUAN BELAJAR MENCIPTA LAGU ANAK USIA DINI

1. Terdapat 4 responden $(26,7 \%)$ yang mendapatkan skor 4,

2. Terdapat 6 responden $(40 \%)$ yang mendapatkan skor 3,

3. Terdapat 5 responden $(33,3 \%)$ yang mendapatkan skor 2, dan

4. Terdapat, 0 responden $(0 \%)$ yang mendapatkan skor 1 .

\section{Tahap Refleksi}

Dari hasil observasi pada pelaksanaan siklus I dapat diketahui bahwa responden masih banyak yang mengalami kesulitan dan kebingungan. Terdapat 5 responden yang belum mengalami ketuntasan pada Pemilihan Notasi Trinada dan Pemilihan Bridge antar Notasi dan masih dibantu oleh teman sejawat/instruktur, responden tersebut adalah tersebut adalah Nurul, Elis, Ena, Kunariyati, dan Weni. Dari ke-5 responden tersebut secara instrumental memang dapat memainkan alat musik, namun struktur atau bentuk melodi dalam proses mencipta. Dan juga terlihat masih belum mandiri

\section{Class Action Research - Siklus III}

Siklus III dilaksanakan selama satu pertemuan yaitu pada tanggal 07 September 2019 sebanyak 15 responden. Pada siklus III, proses belajar mencipta lagu anak usia dini melalui chord berlangsung sesuai rencana pembelajaran yang telah ditetapkan. Data hasil pengamatan terhadap proses pembelajaran pada siklus ini adalah sebagai berikut:

Tabel 5. Hasil Analisis Data Penggunaan Chord dalam Meningkatkan Kemampuan Belajar Mencipta Lagu Anak Usia Dini pada Siklus III

\begin{tabular}{lllll}
\hline No & $\begin{array}{l}\text { Aspek yang } \\
\text { dinilai }\end{array}$ & Kriteria & $\begin{array}{l}\text { Jumlah/ } \\
\text { Anak }\end{array}$ & \% \\
\hline 1 & Pemilihan Notasi & 4 & 6 & $40 \%$ \\
& Trinada dan & 3 & 7 & $46,7 \%$ \\
& Pemilihan Bridge & 2 & 2 & $13,3 \%$
\end{tabular}

\begin{tabular}{rlll} 
antar Notasi & 1 & - & $0 \%$ \\
\hline Jumlah & & 15 & $100 \%$ \\
\hline
\end{tabular}

Berdasarkan tabel di atas, hasil analisis pada siklus III pada pemilihan notasi trinada dan pemilihan bridge antar notasi adalah :

1. Terdapat 6 responden (40\%) yang mendapatkan skor 4,

2. Terdapat 7 responden $(46,7 \%)$ yang mendapatkan skor 3,

3. Terdapat 2 responden $(13,3 \%)$ yang mendapatkan skor 2, dan

4. Terdapat, 0 responden $(0 \%)$ yang mendapatkan skor 1 .

\section{Tahap Refleksi}

Dari hasil observasi pada pelaksanaan siklus I dapat diketahui bahwa responden masih banyak yang mengalami kesulitan dan kebingungan. Terdapat 2 responden yang belum mengalami ketuntasan pada Pemilihan Notasi Trinada dan Pemilihan Bridge antar Notasi dan masih dibantu oleh teman sejawat/instruktur, responden tersebut adalah tersebut adalah Nurul dan Weni. Dari ke-2 responden tersebut secara instrumental memang dapat memainkan alat musik, namun struktur atau bentuk melodi dalam proses mencipta. Dan juga terlihat masih belum mandiri, serta tidak ada motivasi kuat untuk berusaha belajar.

Berdasarkan hasil analisis dari siklus pelaksanaan maka dapat diketahui sebanyak 12 responden $(80 \%)$ di siklus I yang belum mencapai ketuntasan belajar, sebanyak 5 responden $(33,3 \%)$ di siklus II yang belum mencapai ketuntasan belajar, dan 2 responden $(13,3 \%)$ di siklus III yang belum mencapai ketuntasan belajar. Dapat diketahui pula pada siklus ke III, jumlah responden yang mengalami ketuntasan belajar berjumlah 13 orang guru PAUD dengan prosentase $86,6 \%$. Untuk itu, dapat 
disimpulkan bahwa melalui penggunaan chord dalam belajar mencipta lagu anak usia dini pada guru PAUD di Kabupaten Kediri, maka hipotesis tindakan dalam penelitian ini dinyatakan dapat diterima.

\section{KESIMPULAN}

Dapat ditarik kesimpulan dari penelitian ini yaitu melalui pelaksanaan praktik pembelajaran mencipta lagu anak usia dini, sehingga hipotesis tindakan ini dinyatakan berhasil sehingga pembelajaran tuntas.

\section{REFERENSI}

Arostiyani, Devi. (2013). Pemanfaatan Lagu Anak-Anak sebagai Media Pendidikan Karakter di Taman Kanak-kanak Aisyiyah Desa Linggapura Kecamatan Tonjong Brebes. Jurnal Seni Musik Universitas Negeri Semarang.

Dermawanto, Agus. (2012). Penggunaan Media Alat Musik Ritmis dan Melodis Materi Mengenal Alat Musik Ritmis dan Melodis untuk Meningkatkan Aktivitas dan Hasil Belajar Siswa Kelas V SD Negeri 01 Wiyorowetan Ulujami Pemalang. Skripsi. Tidak dipublikasikan. Semarang: UNNES

Hilal, Rangga S. 2007. Alat-Alat Musik. Jakarta Barat: PT. Mapan.

Kamtini, dan Tanjung, Husni Wardi. (2005). Bermain melalui Gerak dan Lagu di Taman Kanak-Kanak. Jakarta: Departemen Pendidikan Nasional.

Kusumaning Ratri, Asri. (2016). Penerapan Metode Penciptaan Lagu Anak Berbasis Tema untuk Guru TK Negeri Pembina Srengat Blitar.

Pekerti, Widia. (2008). Metode Pengembangan Seni. Jakarta: Universitas Terbuka.
Sukohardi, Al. (2009). Teori Musik Umum. Yogyakarta: Pusat Musik Liturgi.

Indra Yeni dan Irdhan Epria Dharma Putra. (2017). Pelatihan Mencipta Lagu Anak pada Guru PAUD di Kecamatan ABTB Kota Bukittinggi dan Kecamatan Tilatang Kamang Kabupaten Agam. Jurnal Anak Usia Dini dan Pendidikan Anak Usia Dini Volume 3 Nomor 3b Desember 2017. Universitas Negeri Padang

Refi Yunanda Wicaksono dan Udi Utomo. (2017). Daya Tarik Lagu bagi Anak Usia Dini: Studi Kasus di TK Pertiwi I Singodutan Wonogiri. Jurnal Seni Musik Universitas Negeri Semarang. 